\title{
An Initial Survey of Arabic Poetry in the Cairo Genizah ${ }^{1}$
}

Dr Mohamed A. H. Ahmed

University of Cambridge \& Woolf Institute

\begin{abstract}
The Cairo Genizah has shown its importance as a fruitful source for the study of both liturgical and secular Hebrew poetry. Yet, although the Cairo Genizah also contains hundreds of poetry fragments written in the Arabic language, its Arabic and Judaeo-Arabic poetry has hitherto received inadequate attention in research literature. This paper explores some of the Genizah's Arabic poems written in both Hebrew and Arabic script, which are held at the Taylor-Schechter Genizah Collections of Cambridge University Library. The paper concludes with a discussion about the importance of the Cairo Genizah to the study of Arabic literature and poetry, and Islamic studies in general, as well as a source for the study of the dissemination of knowledge within medieval Muslim and Jewish elites.
\end{abstract}

\section{Keywords}

The Cairo Genizah; Arabic Poetry; Judaeo-Arabic; Piyyut

\footnotetext{
${ }^{1}$ The author would like to thank the anonymous reviewers for their thorough readings and helpful comments on the paper.
} 


\section{Introduction}

The Cairo Genizah Collections at Cambridge University Library are some of the most significant resources to study the history, languages and cultures of medieval and modern Eastern Mediterranean societies. They contain thousands of fragments written in Judaeo-Arabic (Arabic written in Hebrew script), Hebrew, and Arabic. Cambridge University Library holds the largest part of the Cairo Genizah with about 200,000 fragments of the circa 300,000 fragments that are dispersed around the world.

The Cairo Genizah is a most fertile resource for historical Jewish studies in the medieval and early modern Mediterranean. Through its religious materials it is invaluable to the study, for example, of the Bible, Talmud, and Midrash, and with its wealth of documents, it is the richest source for medieval Middle Eastern Jewish history.

Equally important is the Cairo Genizah's contribution to the study of Hebrew poetry in general and of piyyut in particular. ${ }^{2}$ Accordingly, the study of Hebrew liturgical poetry started to flourish after the discovery of the Cairo Genizah. ${ }^{3}$ This includes the diachronic study of the development

\footnotetext{
${ }^{2}$ Piyyut is Hebrew liturgical poetry that emerged firstly in Palestine during the $4^{\text {th }}$ or $5^{\text {th }}$ centuries CE. With the emergence of Islam in the Arabian peninsula, piyyut composition flourished widely among Jewish communities and was popular within the main two Jewish prayer rites at the time, Palestinian and Babylonian, see Michael Rand, "Paytanic Hebrew", in: Encyclopedia of Hebrew Language and Linguistics, ed. Geoffrey Khan. Consulted online on 30 March 2018 http://dx.doi.org/10.1163/2212-4241_ehll_EHLL_COM_00000680

For more information about Piyyut, see Ezra Fleischer, Hebrew liturgical poetry in the Middle Ages [in Hebrew] (Jerusalem: Magnes, 2007), see also Menahem Schmelzer, "The Contribution of the Genizah to the Study of Liturgy and Poetry", Proceedings of the American Academy for Jewish Research 63 (1997): 164. doi:10.2307/3622601.

${ }^{3}$ From a historical perspective, the study of manuscripts of Hebrew liturgical poetry was impossible before the emergence of Genizah materials. Over the centuries, many poems of early piyyut were being kept in Jewish prayer books, but only the discovery of the Genizah allowed reseachers to put their hands on early piyyut fragments,
} 
of Hebrew sacred poetry, the liturgical culture associated with poetry and the study of the difference between various poetry schools and writing styles in line with Jewish communities from the medieval period until modern times. ${ }^{4}$

The Cairo Genizah was also a fruitful source for the study of Hebrew secular poetry. The amount of Hebrew secular poems, estimated to be some thousands of fragments, is, however, not comparable to the great corpus of Hebrew poetry written for religious purposes. Still, the secular poetry in the Genizah preserves unique pieces that were not discovered in any other sources. ${ }^{5}$

Most studies conducted on Cairo Genizah fragments were mainly concerned with Jewish scholarship. In recent years, however, scholars from other fields have discovered the importance of the Genizah for the social, historical and intellectual study of the Middle East in general. Work on projects concerned with documents written by government officials has, for example, begun in

including hundreds of fragments of Yannai (sixth century CE), who is considered the first payyetan, among others, see Laura S. Lieber, Piyyut (Jewish liturgical and secular poetry), in The Encyclopedia of Ancient History, eds Roger S Bagnall et al. (2012). doi:10.1002/9781444338386.wbeah11186; For more information on Yannai and his liturgical poetry, see Israel Davidson, Mahzor Yannai: A Liturgical Work of the Vllth Century (New York: Jewish Theological Seminary, 1919).

${ }^{4}$ Ezra Fleischer, "The Contribution of the Geniza to the Study of Medieval Hebrew Religious Poetry", in Te 'uda. I. Cairo Genizah Studies [in Hebrew], ed. Mordechai A. Friedman (Tel Aviv: Tel Aviv University, 1980), p. 84; For more information on the contribution of the Cairo Genizah to the study of the Hebrew piyyut, see Menahem Schmelzer, "The Contribution of the Genizah to the Study of Liturgy and Poetry Sources", Proceedings of the American Academy for Jewish Research 63 (1997-2001): 163-179.

${ }^{5}$ Hayyim Schirmann, "Secular Hebrew Poetry in the Geniza Manuscripts", in Te 'uda. I. Cairo Genizah Studies [in Hebrew], ed. Mordechai A. Friedman (Tel Aviv: Tel Aviv University, 1980, pp. 97-123. To give an example, the Cairo Genizah has provided us with information about the life of Judah ha-Levi (1075-1141 CE), who wrote both religious and secular Hebrew poetry in Spain, as were for example identified by Goitein, see Shelomo Dov Goitein, A Mediterranean Society, Volume V: The Individual (Berkeley: University of California Press, 1988), pp. 448-468. Other well-known poets who wrote secular poetry were also identified in Cairo Genizah fragments, including Samuel ha-Nagid, Solomon ibn Gabirol, Moses ibn Ezra and Abraham ibn Ezra, see Menahem Schmelzer. "The Contribution of the Genizah to the Study of Liturgy and Poetry Source", Proceedings of the American Academy for Jewish Research, 63 (1997-2001): 176. 
Princeton under the direction of Prof. Marina Rustow, showing the connections between the Muslim courts and the Jewish communities through the agency of Jewish clerks and scribes. ${ }^{6}$

The Cairo Genizah adds new perspectives to other fields of Arabic studies too, with scholars discovering the usefulness of the materials for their own field in recent years. ${ }^{7}$ Pertaining to Arabic poetry, a treasure trove of fragments is still waiting to be discovered. In the following sections, this paper will examine examples of Judaeo-Arabic and Arabic poetry found in the Genizah which appear to have circulated in Egypt among Jewish communities in the medieval and later periods.

\section{Arabic language poetry in the Cairo Genizah}

\subsection{Overview}

Poetry is one of the earliest genres of Arabic literature and certainly considered its most popular. As Arabic speakers, Jews adopted this creative literary writing in the pre-Islamic period. ${ }^{8}$ There is evidence of shared interest in poetry between Jews and Muslims from the seventh century onwards, which lasted through the ages until modern times. The emergence of secular Hebrew poetry in al-Andalus was a direct consequence of exposure to Arabic poetic traditions. ${ }^{9}$ Al-Harīzī

\footnotetext{
${ }^{6}$ For more information about the study of Arabic script legal documents from the Cairo Genizah, see Geoffrey Khan, Arabic Legal and Administrative Documents in the Cambridge Genizah Collections (Cambridge: Cambridge University Press, 1993).

${ }^{7}$ See for example Bilal W. Orfali and Maurice A. Pomerantz, “A Lost Maqāma of Badī‘ al-Zamān al-Hamad̄ān̄̄?”, Arabica 60 (2013): 245-271.

${ }^{8}$ For instance, the Jewish poet Samaw' al ibn Jarīd ibn 'Ādiyā' who lived in Arabia during the $6^{\text {th }}$ century. For more information, see Jacobs Joseph and Mary W. Montgomery, The Jewish Encyclopedia 11 (New York: Funk and Wagnalls, 1906), pp. 14-15.

${ }^{9}$ Arie Schippers, Spanish Hebrew Poetry and the Arabic Literary Tradition: Arabic Themes in Hebrew Andalusian Poetry (Leiden: Brill, 1994); Peter Cole, The Dream of the Poem Hebrew Poetry from Muslim and Christian Spain, 950-1492 (Princeton University Press, 2007).
} 
(ca. 1166-1225) was one of the Jewish poets who wrote in both Arabic and Hebrew. Medieval Judaeo-Arabic poetry (Arabic poetry written in Hebrew script) ${ }^{10}$ can be found in many fragments in the Cairo Genizah, which adds further evidence of this intertwined Judaeo-Islamic heritage.

Unlike the Hebrew liturgical and secular poetry discussed above, Arabic and Judaeo-Arabic poetry in the Cairo Genizah is an area that has hitherto received very little attention. ${ }^{11}$ While many scholars have worked on the Hebrew poetry, with extensive collections collated in books and on websites, ${ }^{12}$ the Arabic material has been largely neglected. If mentioned at all in catalogues, identification and labelling is mostly limited to "Arabic poetry", without any further details, and the large majority of sources still await description.

\subsection{Judaeo-Arabic poetry}

A trial survey of the Arabic poetry in the Cairo Genizah showed very encouraging results. Poetry by various Fatimid authors, such as Tamīm al-Fātīmī (948-984) and Ibn Abī Ḥuṣayna (9981064) can be found alongside older poems composed by famous Abbasid poets, like Abū Firās al-Ḥamadān̄̄ (932-967), al-Khubzaruzzī (d. 939) and Khālid al-Kātib (d. 876).

\footnotetext{
${ }^{10}$ Geoffrey Khan, “Judaeo-Arabic.” in Encyclopedia of Arabic Language and Linguistics, ed. Lutz Edzard \& Rudolf de Jong (Leiden: Brill, 2007), pp. 526-536.

${ }^{11}$ Hartwig Hirschfeld published two articles about some Arabic poetry in the Cairo Genizah, see "The Arabic portion of the Cairo Genizah at Cambridge", The Jewish Quarterly Review 15 (January 1903): 167-181; "The Arabic portion of the Cairo Genizah at Cambridge: A poem attributed to AlSamau'al", The Jewish Quarterly Review 17 (April 1905): 431-440.

12 There are more than 88,000 titles of Hebrew liturgical poems piyyutim that were catalogued by "The Ezra Fleischer Geniza Research Project for Hebrew Poetry". See also Israel Davidson and Jefim Schirmann, Otsar hashirah yeha-piyyut [Thesaurus of mediaeval Hebrew poetry] (New York: Ktav Pub. House, 1970).
} 
The genres and poetic themes are variable and wide-ranging, including: love poetry ( hazal), ${ }^{13}$ elegy (rithā'), ${ }^{14}$ descriptive poetry (wasf $),{ }^{15}$ eulogy (madīh) $),{ }^{16}$ a strophic poetic form (muwashshah), ${ }^{17}$ dialectical poetry, or "shout" (zajal). ${ }^{18}$ Some pieces are conserved in both Arabic and Hebrew script next to each other, we can find eulogies for the prophet, and handbooks about poetic metres.

In the following the paper explores a selection of some Arabic poems written in both Hebrew and Arabic script held at the Cairo Genizah collection in the Cambridge University Library. The

\footnotetext{
${ }^{13}$ The term ghazal refers to the poet's description of the beloved woman, his love and longing for her. From a historical point of view, ghazal has a long record in Arabic literary traditions. Arabic love poetry was developed throughout centuries; from pre-Islamic period until modern times. Each period, such as pre-Islamic, Fatimid and Abbasid, has its unique features of ghazal poetry. See Kamāl Khalāylī, Jamharat rawā 'i al-ghazal fí l-shi ' $r$ al'Arabī, (Beirut: al-Mu 'assasa al- 'Arabīya lil-Dirāsāt wa-al-Nashr, 1993); Julie Scott Meisami and Paul Starkey, Encyclopedia of Arabic literature (New York: Routledge, 1998), pp. 249-250.
}

${ }^{14}$ rithā', means also dirge or lament, refers to a traditional Arabic poetic genre that emerged from pre-Islamic period. rith $\bar{a}$ ' mainly was composed by women to bewail their next of kin. Al-Khansā' (died $665 \mathrm{CE}$ ) was among the most famous poets for her marāthi poems on her two brothers. Not only women, but also male poets started to compose and to develop rith $\bar{a}^{\prime}$ writing after the beginning of Islam. For more information, see Meisami and Starkey, Encyclopedia, 663-664.

${ }^{15}$ wasf, meaning "description" in Arabic, is a poetic Arabic literary tradition used to describe certain objects thoroughly and considered a key element in Arabic poetry. The pre-Islamic poets start their poems mostly with wasf to describe the journey, the beloved or to describe the wine, see 'Abd al-'Azīm al-Qināwī, al-Wașffì l-shi 'r al- 'arabì (Cairo: Sharikat Maktabāt wa-Matba āt Muștafa al-Bābi al-Halabī wa-Awlādihi, 1949), p. 44. See also Akiko Sumi, Description in Classical Arabic Poetry: Wasf, Ekphrasis, and Interarts Theory (Leiden: Brill, 2003).

${ }^{16}$ madī $h$ is a generic Arabic term that describes the panegyric poetry. madīh is considered one of the oldest types of Arabic poetry, and includes the praise of rulers, heroes, the prophet Muhammad and God. See Meisami and Starkey, Encyclopedia, 482-484.

${ }^{17}$ pl. muwashshahāt, originally emerged in Spain. muwashshah usually composed of five stanzas, in which each stanza has a certain rhyme system. The initial part of the last stanza contains the kharja (exit), which is usually composed in colloquial Arabic or Romance. For more information about the muwashshah, see Meisami and Starkey, Encyclopedia, 563-566; Arie Schippers, "Muwaššaḥ”, Encyclopedia of Arabic Language and Linguistics, ed. Lutz Edzard et al. Accessed March 20, 2018. doi:http://dx.doi.org/10.1163/1570-6699_eall_EALL_SIM_000011.

${ }^{18}$ zajal, a dialectical poetry, donates diverse types of poems composed in colloquial Arabic. For more information see Meisami and Starkey, Encyclopedia, 819. 
poems are transcribed and also transliterated into Arabic script, followed by an English

translation.

\subsection{Love poetry}

The genre of Arabic love poetry is a favourite of Arabic literature. ${ }^{19}$ Thus, it is no surprise to see that many poems found in the Cairo Genizah are written within a love theme. The Genizah love poetry is composed in different poetic styles and comes from various time periods, as will be shown below. To begin with, in the fragment T-S Ar.13.4, there are two verses of an Arabic poem written by a famous Abbasid poet known by his nickname al-Khubzaruzzī (d. $939 \mathrm{CE}) .^{20}$ The poem is written in the Arabic poetic metre $a l-k \bar{a} m i l^{21}$ and reads:

T-S Ar.13.4 (2r) $)^{22}$

ביני ובינך יא טלום אלמוקפו אלחאכם אלעדל אלגואד אלמנצפו

\footnotetext{
${ }^{19}$ The majority of Arabic poets wrote ghazal poetry, see Khalāylī, Jamhara, 12. See also, Thomas Bauer, Liebe und Liebesdichtung in der arabischen Welt des 9. und 10. Jahrhunderts: eine literatur- und mentalitätsgeschichtliche Studie des arabischen Gazal (Wiesbaden: Otto Harrassowitz, 1998), p. 18.

${ }^{20}$ His full name was Naṣr ibn Aḥmad ibn Ma'mūn al-Bașrī Abu al-Qāsim. He was famous for his ghazal poetry. His nickname al-Khubzaruzzī came from his work as a baker of a certain Iraqi bread. For more information, see Muḥammad Ḥasan Āl-Yāsīn, "Edition of Dīwān al-Khubzaruzzī, Nașr ibn Aḥmad al-Bașrī”, Iraqi Academy of Science Journal 40 (1) (1989): 93-95. See also Meisami and Starkey, Encyclopedia, 443. Al-Tha' ālibī provided an entry about the poet al-Khubzaruzzī which includes a considerable number of his poems: 'Abd alMalik ibn Muḥammad Tha 'ālib̄̄, Yatīmat al-Dahr fì mahāsin ahl al- 'așr, ed. Mufīd Muḥammad Qumayḥa (Beirut: Dār al-Kutub al- 'ilmiyya, 2000), 428-432. Āl-Yāsīn edited a manuscript of the al-Khubzaruzzī Dīwān, which he claims to be the only extant manuscript of al-Khubzaruzzī.

${ }^{21}$ The Arabic poetic metre al-'arū Arabic metres. Each metre $b a h r r$ has its unique structure, which depends mainly on rhythmic core that alternates between longer and shorter prosodic segments. For more information, see Abū l-Fatḥ 'Utmān Ibn Jinnī, Kitāb al'arūụ, ed. Aḥmad al-Hayb (Kuwayt: Dār al-Qalam, 1987); 'Abd al- 'azīz 'Atīq, 'ilm Al- 'arūẹ wa-al-Qāfiya (Beirut: Dār al-Nahḍah al- 'Arabīyah lil-Ṭibā 'a wa-al-Nashr, 1967); Dmitry Frolov, Classical Arabic Verse: History and Theory of 'Arū (Leyde: Brill, 2000).

${ }^{22}$ All Arabic transliterations and English translations in this paper have been done by the author.
} 


\section{Arabic transliteration:}

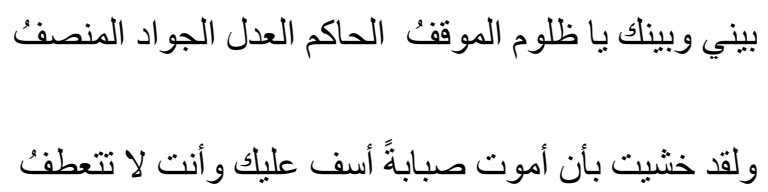

\section{Translation:}

“O tyrant, between you and me is an opinion, (which is) a fair just honest judge.

I was afraid of dying out of love, I am sorry about you, and you do not sympathise."

When comparing this Judaeo-Arabic version to the version of the same Arabic poem found in Arabic poetry databases, it reads slightly differently. In the paper by $\bar{A} l-Y \bar{a} s \bar{n},{ }^{23}$ the version of the same poem reads as:

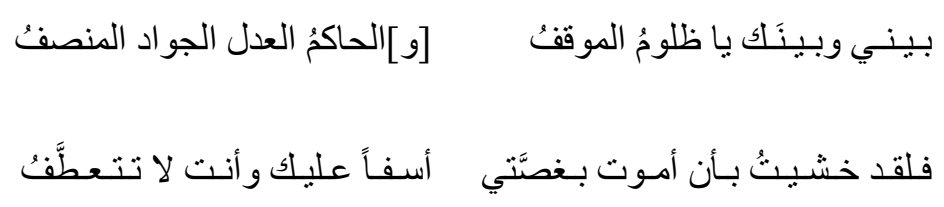

\section{Translation:}

"O tyrant, between you and me is an opinion and a fair just honest judge.

I was afraid of dying with sorrow (in my heart) being sorry about you, and you do not sympathise.”

${ }^{23}$ Āl-Yāsīn, “al-Khubzaruzż̄”, vol 40 (3 \& 4): 132. 
The paper by Āl-Yāsīn provides an edition of Dīwān al-Khubzaruzzī based on a manuscript held in the Institute of Arabic Manuscripts in Cairo, which is dated to September $1776 .{ }^{24}$ The comparison between the version of the Arabic poem in the Cairo Genizah fragment and the version edited by Āl-Yāsīn shows some variations. The first verse is the same in the two versions. Only Āl-Yāsīn added the Arabic conjunction $w \bar{a} w$ between brackets before the word al-Hākim "judge" supplied by a comment in the footnote says: "an addition, which is required from the context". ${ }^{25}$ Indeed, the addition of the Arabic conjunction $w \bar{a} w$ by Āl-Yāsīn has changed the meaning of the whole verse. ${ }^{26}$ Apparently, the original poem contained no $w \bar{a} w$ in the first verse. The difference in the second verse between the two poem versions is the phrase (أموت بـغصَّني) instead of (أموت صبابة). Another variation occurs in the second verse, it starts with (ولقد) in the fragment version of the poem, whereas it begins with (فلق) in the Arabic edited version. These are slight variations between the two versions, and they do not affect the poem regarding metre and rhyme.

The Cairo Genizah does not only hold classical love poetry, but it has preserved early modern poetry as well. The Judaeo-Arabic fragment T-S NS 31.19 contains several verses from a popular poem attributed to Aḥmad bin $\mathrm{Sa}^{\prime} \overline{1} \mathrm{~d}$ al-Busa ${ }^{\prime} \overline{1} \mathrm{~d} \overline{1}(1710-1783 \mathrm{CE})$, who was the first ruler of Oman. Later the poem was turned into a song, which was popular in the Gulf during the early twentieth century. The poem is written in the poetic metre al-kāmil: ${ }^{27}$

\footnotetext{
24 Āl-Yāsīn, “al-Khubzaruzzī”, vol 40 (1): 97.

25 Arabic: “زيادة بقتضيها السياق", see Āl-Yāsīn, “al-Khubzaruzzīi”, vol 40 (3 \& 4): 132.

${ }^{26}$ See the variations in the English translations of the two versions.

${ }^{27}$ This song was played first by the Bahraini singer Dhāḥ̄i ibn Walīd (1898-1941), and afterwards by the Kuwaiti singer 'Awad al-Dūkhī (1932-1979).
} 


\section{T-S NS 31.19 (r1):}

יא מן הוואה עזהו ואדלני כיף

אלט סביל אלא וצאלך דלני

וצאלתני למא מלוכת חשאשתי

ואגבת מן ב[עד] אלוצאל הגרתני

\section{Transliteration:}

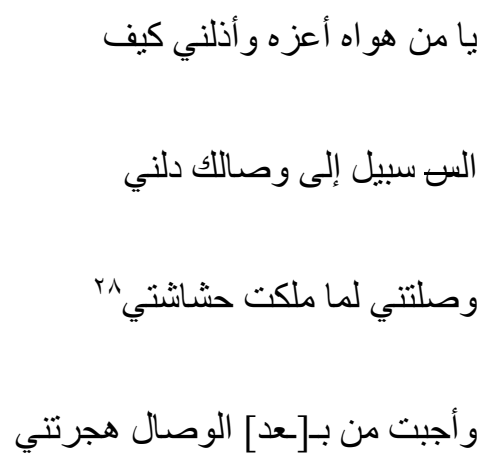

\section{Translation:}

"O whose love strengthened him and humiliated me

How to reach you? Guide me!

You were intimate with me when you owned my last breath of life,

and you replied after coupling, you departed from me".

${ }^{28}$ The Judaeo-Arabic spells this word with long vowel $w \bar{a} w, w \bar{a} s ̦ a l t a n \bar{\imath}$, instead of wașaltanī in the Arabic version of the poem, probably in an effort to mark the /a/ vowel. Similarly we find malukta, instead of malakta. 
This poem suggests that modern Arabic poetry from the eighteenth century was also popular among Jews at the time, enabling us to trace the historical development of Jewish-Muslim heritage regarding Arabic literature and Arabic poetry in the Ottoman period.

Another beautiful piece of Arabic love poetry is found in the fragment T-S Ar.37.127, which contains a collection of Arabic short poems or pieces of Arabic poems. One of the poems in the fragment was written by a famous Fatimid poet called Ibn Abī Ḥuṣayna (998-1064).

The fragment holds two verses from a long Arabic poem in Dīwān Ibn Abī Huṣayna, which comes in 35 verses and uses the most popular Arabic poetic metre al-Tawīll. ${ }^{29}$ The two verses in the fragment are exactly the same as the two verses found in the complete poem in Ibn Abī Huṣayna's Dīwān, which is written in the Arabic poetic metre al-țawìl:

T-S Ar.37.127 (1r)

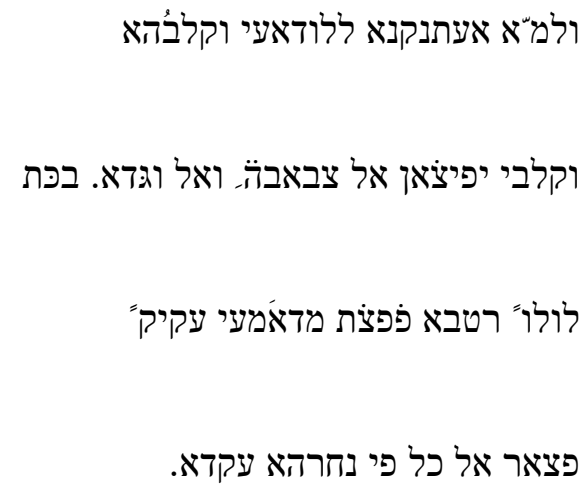

Arabic transliteration:

ولمّا اعتنقتا للوداع وقلُبها

\footnotetext{
${ }^{29}$ Ibn Abī Ḥuṣayna and Abū al- 'Alā' al-Ma arrī, Dīwān Ibn Abī Hușayna, ed. Muhammad As 'ad Ṭalas (Beirut: Dār
} Șādir, 1999), p. 227. 


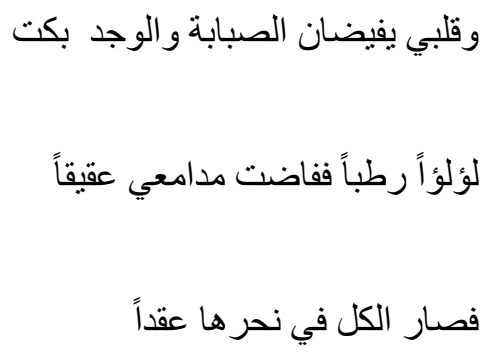

\section{Translation:}

"When we embraced for farewell, at the moment that her heart

and mine were full of passion and love, she shed

tears of sprinkled pearls. My tears, subsequently, flooded with onyx..$^{30}$

At that point, everything (pearls ${ }^{31}$ and onyx) became a necklace on her neck".

A beautiful piece of ghazal poetry is found in T-S NS 164.173, which also shows Tiberian

Hebrew vocalisation. ${ }^{32}$ The poem comes in Arabic poetic metre majz $\bar{u}^{\prime}$ al-ramal, and reads:

\section{T-S NS 164.173 (1v)}

30 ' $a q \bar{\imath} q$, or Onyx is mostly connected to the red coloured jewels and is used to describe some fruits, like pomegranate and berries, see the various conventions of the term in Shihāb al-Dīn Al-Nuwayrī, Nihāyat al-Arab fi funūn al-Adab, Vol. 11 (Cairo: al-Mu' assasa al-Mișriyya al- 'Āmma lil-Ta' lîf wa-l-Tarjama wa-l-Ṭibā 'a wa-l-Nashr, 1998), pp. 33, $57,93,102-105,111-116,255,270,282$. Thus, the term 'aq $q$ (onyx) may refer in this verse, probably, to tears of blood.

${ }^{31}$ Pearls in Arabic poetry used to refer to tears. For the reference of pearls that describe tears and teeth at the same time, see for instance Thomas Bauer, Die bad̄̄ 'iyya des Nāṣ̂f al-Yāzī̄̄i und das Problem der spätosmanischen arabischen Literatur, in Reflections on Reflections: Near Eastern Writers Reading Literature: Dedicated to Renate Jacobi, ed. Angelika Neuwirth, Andreas C. Islebe, and Renate Jacobi (Wiesbaden: Reichert Verlag, 2006 ), p. 102.

${ }^{32}$ For more information about the Tiberian vocalisation, see Geoffrey Khan, "Vocalised Judaeo-Arabic Manuscripts in the Cairo Genizah", in From Sacred Source: Genizah Studies in Honour of Professor Stefan C. Reif. Cambridge Genizah Studies Series, ed. Ben Outhwaite and Siam Bhayro (Leiden: Brill, 2010), pp. 201-218. https://doi.org/10.1163/EJ.9789004190580.I-420.53. 


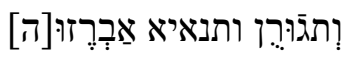

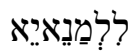

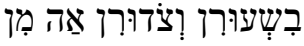

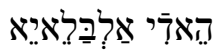

אַה מְן פְעִל אלכטאיא

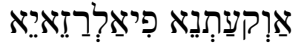

Arabic transliteration: ${ }^{33}$

كَم بُدورِفي السبايا

ذَات نورٌ بالمر ايا

وتغنورٌ وثنايا أبرزوهـ[]

للمنايا

بشعورٍ وصدورٍ آه من

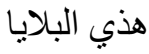

آه من فعل الخطايا

\begin{abstract}
${ }^{33}$ There are two grammatical mistakes in the poem according to prescriptive grammar. The first is the nominative case of the noun bidürun (full moons), which should be in the genitive case bidürin. The word kam does not enquire about measurement or numbers. Therefore, bidūrin is not a tamyīz in this verse. According to the context, the poet wonders of the countless number of women who are in captivity. For more information about the different cases of tamyiz and expressions of measures, see David Justice, The Semantics of Form in Arabic in the Mirror of European Languages (Amsterdam: J. Benjamins Pub. Co, 1987), pp. 316-320. The other mistake is found in the noun nürun (light), which should be in the genitive case nürin instead.
\end{abstract}




\section{Translation:}

"How many full moons ${ }^{34}$ in the captivity,

with light (reflected) in the mirrors,

with mouths and front teeth, they exposed them to

fate,

with hair and breasts. I suffer from

such calamity.

\section{I suffer from conducting sins}

that brought me to disasters."

The poem in this fragment not only shows the importance of the Cairo Genizah as an abundant source for the study of Arabic poetry that was being circulated among the Jewish community in Egypt in the medieval period but also provides us with information about the reading tradition of

Arabic poetry at the time. ${ }^{35}$

\footnotetext{
34 The Arabic term badr (full moon), pl. bidūr, is typically compared to the beauty of the beloved in Arabic poetry. Arabic poetry uses metaphors to describe women's beauty indirectly. For instance, the moon and the face of a beautiful woman became synonymous, see for instance Yahya Ma rūf and 'Āṭ̂̄ Bayāt, "Jamāliyyāt al-taghazzul bilrimūz al-' untawiyya fī al-shi 'r al-jāhilī”, Fașaliyyat al-Naqd w-al-Adab al-Muqāran Journal 2 (2012): 133-135; Bauer, Liebe und Liebesdichtung, 222-226.

${ }^{35}$ Because of the Tiberian vocalisation, the poem in this fragment presents a special case of poetry written in JudaeoArabic. The vocalisation provides us with a close picture of the actual reading of the poem. It is interesting to note

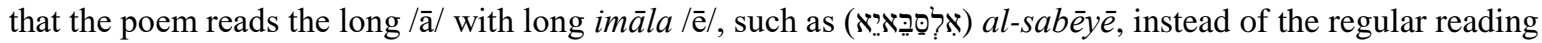

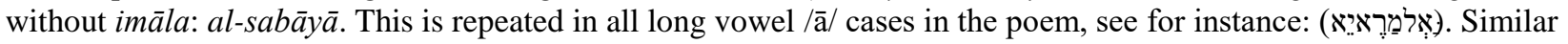
to this case, Khan pointed out that the manner of representing Hebrew vowels in Arabic script by Karaite scribes
} 


\subsection{Love poem from the book "Alf layla wa-layla" (A Thousand and One Nights)}

Another piece of love poetry found in the fragment T-S NS 102.104, written in Arabic poetic metre al-kämil, is very similar to a poem taken from one copy of the famous Arabic book "Alf

layla wa-layla". ${ }^{36}$

T-S NS 102.104 (1r):

שוקי אליך [....... דיד ואלדמע

יגרח מקלתים ויזידُ

חשם אלזמאן כמא סעא בפראקנא

אן אלפראק עלי אלמחב שדידُ

\section{Arabic transliteration:}

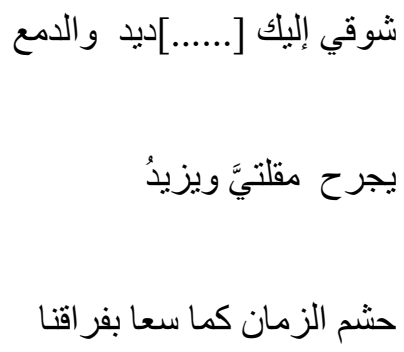

reflects the Tiberian pronunciation tradition, see Geoffrey Khan, "Vowel Length and Syllable Structure in the Tiberian Tradition of Biblical Hebrew”, Journal of Semitic Studies 32/1 (1987): 29.

https://doi.org/10.1093/jss/XXXII.1.23

${ }^{36}$ Alf layla wa-layla: a 'nī Kitāb Alf layla wa-layla, ed. William Hay MacNaghten (Calcutta, 1839), II: 235. It is important to note that the most accurate edition of the book Alf layla wa-layla was edited by Muhsin Mahdī: The Thousand and One Nights (Alf Layla Wa-layla) From the Earliest Known Sources: Arabic Text Edited With Introduction and Notes By Muhsin Mahdi, (Leiden: Brill, 1984). The Arabic poem in the fragment T-S NS 102.104 is not found in Mahdī's edition. However, it is quite interresting to show how Arabic poems were circulated in various Judaeo-Arabic resources. 


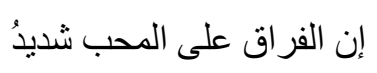

\section{Translation:}

"My longing for you $[\ldots]$ and tears

wound my eyes and even more.

Time is put to shame as it strives to separate between us.

For the lover, painful is the separation."

The poem in the fragment is similar to a poem in the book "A Thousand and One Nights" in terms of poetic metre and the rhyme. However, there are some variations between the two versions. Unfortunately, the first half of the first verse in the fragment is stained, and only two words can be clearly identified. These two words are the same in the Arabic version of the poem

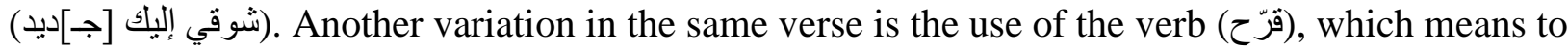
become gangrenous, instead of the verb (يجرح), which means to injure. The significant difference, however, is in the second verse, which starts with a completely different sentence in the first half

of the verse: ${ }^{37}$

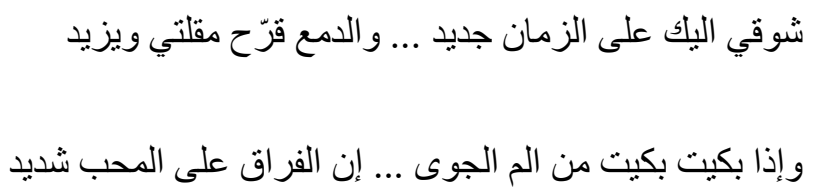

\section{Translation:}

"My longing to you for the time is new and tears

\footnotetext{
${ }^{37}$ Alf layla wa-layla: 235.
} 
injured my eyes and more they do.

If I weep, I do because of the pain of love.

For the lover painful is the separation."

This example shows how poetry citations from the most well-known Arabian folk-tale books were being quoted and read in Jewish circles.

The variations in this poem, among other examples in this paper, shed light on the potential benefit of the fragments of the Cairo Genizah Collections to the study of Arabic poetry. Further studies will allow us to compare different sources, amend weak versions or perhaps find new poems.

\section{5 muwashshah}

The muwashshah - or "a strophic poetic form", plural muwashshahāt, is strophic poetry in classical Arabic. It was established and developed in Muslim Spain from the ninth century. The muwashshah usually consists of a multi-lined strophic verse poem written in classical Arabic, usually consisting of five stanzas, alternating with a "kharja - exit" with a running rhyme. The muwashshah starts with one or two lines which matched the second part of the poem in rhyme and metre. Although the biggest part of the muwashshah is mostly written in classical Arabic, the kharja comes typically in colloquial Arabic, sometimes in Romance. ${ }^{38}$

There is a considerable number of fragments in the Cairo Genizah that contain Arabic muwashshahāt written in Judaeo-Arabic. One fragment (T-S Ar.36.129) has a complete Arabic

\footnotetext{
38 For more information, see Meisami and Starkey, Encyclopedia, 563-566; Arie Schippers, "Muwaššah", Encyclopedia of Arabic Language and Linguistics, ed. Lutz Edzard et al. Accessed March 20, 2018. doi:http://dx.doi.org/10.1163/1570-6699_eall_EALL_SIM_000011.
} 
muwashshah, which is found in an Arabic book about the art of muwashshah written by the wellknown Muslim poet Ibn Sanā' al-Mulk (1155-1211). ${ }^{39}$

T-S Ar.36.129 (1r):

כם באלקדוד אלליאק תחת אללמם . מן אקמר עואט . באנמל ובנאן מתל אלענם לם תנבר ללעאט .

אהוי רשא סאחרא . מנה אלהוי מא אקתלה . קד מסכת טאירא . אלחאטה קלבי ולה . ולם יזל סאגרא עלי למי קד עללה . יא חאכמא גאירא קתלת מן לא דנב לה . למא גדא קאדרא אצ'י קליל אלמעדלה כף סטות אלרחמן אדא חכם . בין אלברי ואלכאט. . סטות באל הימאן טלמא ולם . תסתבצרי יא סאטי. יא מן ירום רשדי. דע בלנבי הדא אלעתאב . קד דבת מן תעבי סקמא פמא נקוי תעב . באס אלהוי צעב לכל מן דאק צעב. רמית באלאגפאן (מ)תל אלסהאם וצחת מן אניאטי . קד רדת אל אגפאן קלבי דמים . מא צבת לי כיאט.. הן אלטבא אלשמוס . קניצהן אלציגם . מא אן להא מן כנס . אלא אלקלוב אל הים . אל קרב מנהא ערם . ואל בעד מנהא מאתם . תלך אל

\footnotetext{
${ }^{39}$ Ibn Sanā' al-Mulk, Dār al-țirāz fì 'amal al-muwashshahāt, ed. Jawdat Rikābī (Beirut: al-Maṭba 'a al-Kāthūlīkīya, 1949), 60.
} 
אלשפאה אל לעם . ישפי בהן אל מגרם . להא לחאט נעם . תרנו אלי מן תסקם.

באעין גר״א ותבתסם . ען גוהר אל אסמאט . קצא להא אל

גיראן אן תכתתם . פי מצמר אל אנמאט.

\section{Arabic transliteration:}

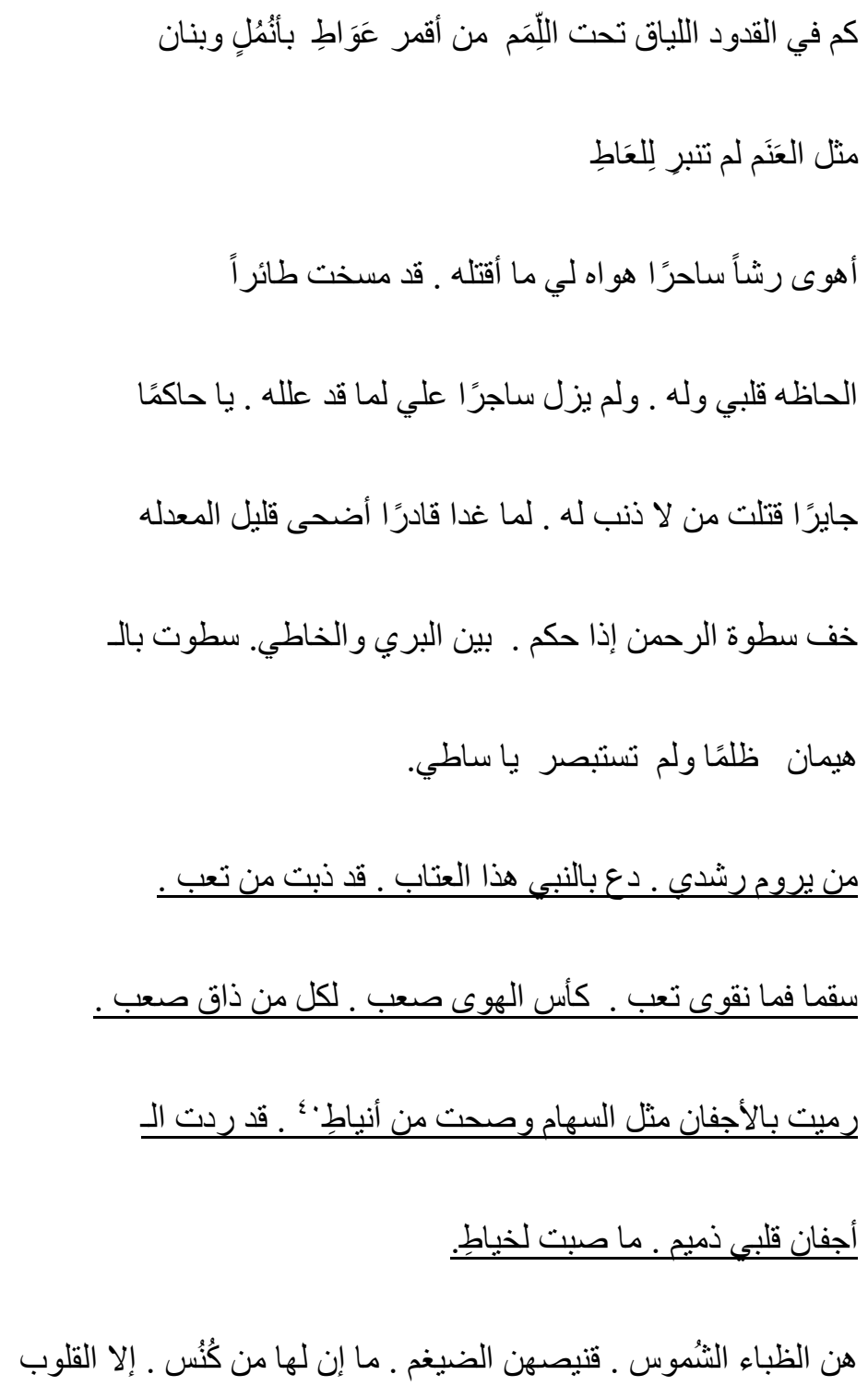

هن الظباء الثُموس ـ قنيصهن الضيغم ـ ما إن لها من كُنس ـ إلا القلوب

${ }^{40}$ Singular $n \bar{u} t$, means a heart or a vein in the heart, see Ibn Sanā' al-Mulk, Dār al-tirrāz, 146. 


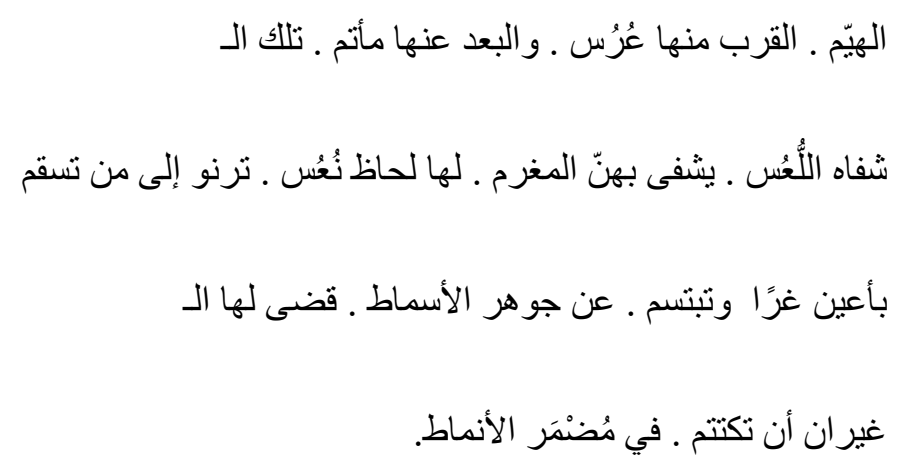

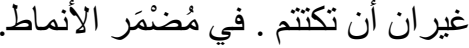

\section{Translation:}

"How many long necks ${ }^{41}$ like moons are hidden under perfect body shapes with long hair, with fingertips and fingers like 'anam tree, ${ }^{42}$ which were not for sale. ${ }^{43}$

I love a charming Gazelle. ${ }^{44}$ Its love is a murderer. I have metamorphosed into a bird, its eyes have driven my heart mad. It is still imprisoned because of what happened to it. O oppressive ruler

you have killed someone without guilt. When he came into power, he became less just.

\footnotetext{
${ }^{41}$ In Arabic classical poetry, women's beauty was governed by some physical features, such as whiteness, big eyes, tallness and a long neck, see Doris Behrens-Abouseif, Beauty in Arabic culture (Princeton: NJ: Markus Wiener, 1998).

42 al- 'anam is a name of an Arabic tree with delicate branches which was likened to the fingertips of girls, singular 'anama, see: Ibn Manz̄ūr, Lisān al- 'Arab, vol.12 (Beirut: dār Șādr, 1992), p. 429. See also Edward William Lane, Arabic-English Lexicon (London: Willams \& Norgate, 1863), p. 2178.

${ }^{43}$ Literally: "which were not bestowed upon any payer".

44 The comparison between the beloved woman and the gazelle is considered one of the most common features of classical Arabic love poetry, see Ma rūf and Bayāt, "Jamāliyyāt al-taghazzul", 135-136; Meisami and Starkey, Encyclopedia, 249.
} 
Respect the authority of the Most Merciful (God) when he arbitrates between innocent and guilty. You, captor, have unjustly subjugated

the man madly in love (with you), and you did not contemplate.

You who searches for reasonableness, by the prophet abandon your blame. I have dissolved because of tiredness. Being ill and cannot sustain this tiredness. The cup of love is oppressive. oppressive it is for who tasted it.

I was thrown by eyelids which were like arrows, and I cried from the (pain) in my heart. The eyelids made my

heart miserable. ${ }^{45}$

They are the Gazelles like suns, ferocious lion is their hunting. ${ }^{46}$ They have no shelters but passionate hearts. To be near to them is joy. To keep away from them is grief. These beautiful $\operatorname{lips}^{47}$ the lover is healed by them. They have downturned eyes, which look at the person being infected by them with deceiving eyes and then they (the eyes) laugh. About the thread (of a pearl necklace)

The Jealous ruled that she must keep it secret, deeply hidden”.

\footnotetext{
45 The Arabic sentence (ماصبت لخياطِ) is obscure.

${ }^{46}$ The poet in this verse compares the beloved women to the gazelle, and he compares the lover to a lion going after gazelles for hunting.

47 The Arabic term $l u$ 'su لُعْ in this verse applied to women or girls who have little blackness in their lips as an indication of their beauty, singular la 'sā' لعساء, see Ibn Manzūr, Lisān al- 'Arab, vol. 6 (1992), 207.
} 
The Arabic version in the book by Ibn Sanā' al-Mulk reads: ${ }^{48}$

$$
\begin{aligned}
& \text { كم في قدود البان تحت اللّلّمَم من أقمر عَوَاطِ } \\
& \text { بأنُعُلٍِ وبنان مثل العَنَم لم تنتبرِ لِعَاطِ }
\end{aligned}
$$

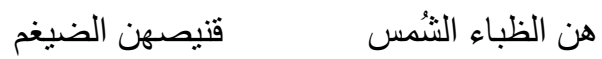

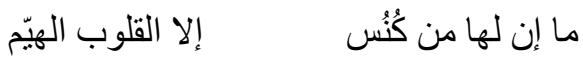

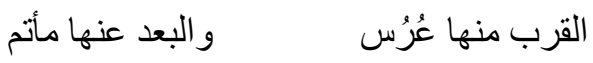

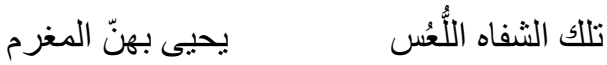

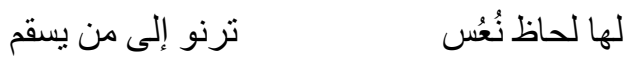

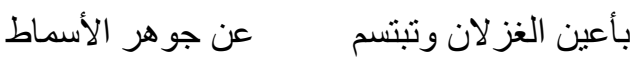

$$
\begin{aligned}
& \text { قضى لها الغيران أن تكتتم في مُضْمَر الأنياط }
\end{aligned}
$$

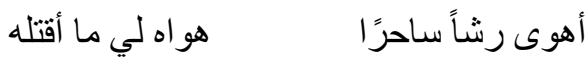

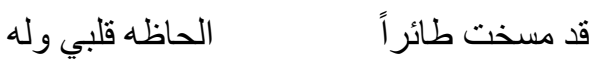

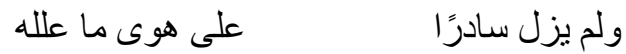

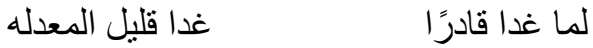

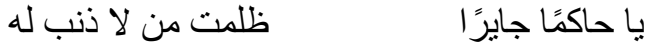

$$
\begin{aligned}
& \text { خف سطوة الرحمن إذا حكم بين البري والخاطي }
\end{aligned}
$$

${ }^{48}$ Ibn Sanā’ al-Mulk, Dār al-titrāz, 60. 


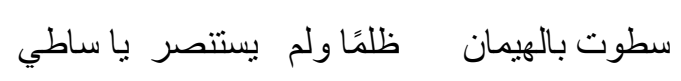

The comparison between the two versions of the muwashshah reveals a number of exciting findings. First of all, there is a difference between the two versions concerning the order of some parts of the muwashshah. While the two start with the same openings, the second part in the muwashshah in the fragment comes as the third part in the muwashshah found in the book by Ibn Sanā' al-Mulk. The most significant feature in the Judaeo-Arabic version, however, is that it contains a complete part of the muwashshah which is missing from the Arabic version (underlined in both transcription and translation). The missing part comes in the second place and starts with (يا من يروم رشدي). As we will also see in other examples, some of the fragments have more verses or parts than what is found in the available Arabic poetry databases.

\subsection{Religious poetry}

Religious Arabic poetry has a place in some fragments in the Cairo Genizah, too. In the fragment T-S Ar.54.31, there are two Arabic poems that were apparently copied from an Islamic source called Wafayāt al-a 'yān wa-anbā' abnā' al-zamān - The death of honourable persons and the frightening of the sons of the epoch written by the Shāfi 'ī Islamic scholar Ibn Khallikān (12111282). ${ }^{49}$

The two Arabic poems written by the poet Ibn Wakī al-Tanīsī (d. 1003) are written in the Arabic poetic metre al-mutaqārib:

T-S Ar.54.31 (1v)

49 Ibn Khallikān, Wafayāt al-a yān wa-anbā' abnā' al-zamān, ed. Iḥsān 'Abbās and Wadād Qāḍ̄i (Beirut: Dār Ṣādir, 1978). 


\section{Arabic transliteration:}

$$
\begin{aligned}
& \text { بقدر العلو يكون الهجوط فِاياك و الرُتب } \\
& \text { العالية وكُن في مكان إذا ما سقطت تقوم } \\
& \text { ورجليك في عافيه } \\
& \text { وله } \\
& \text { لقد رضيت همني بالخمول وحادت عن } \\
& \text { الرُّب العالية . . وما جهت طيب طعم } \\
& \text { العُلا . ولكنها تؤثر العافيه }
\end{aligned}
$$

\section{Translation:}

"You will fall with the same speed as you go up. Avoid high

positions and take a place, from which if you fall you 
can get up with unharmed legs.

Another poem by him:

My ambition is satisfied by being lazy and avoiding

high positions. It (my ambition) is not unaware of the stunning taste

of the sublime; but rather it prefers safety."

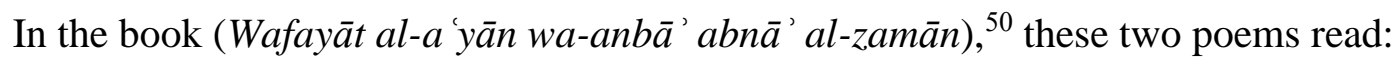

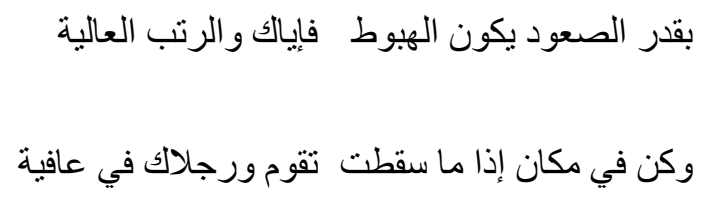

And

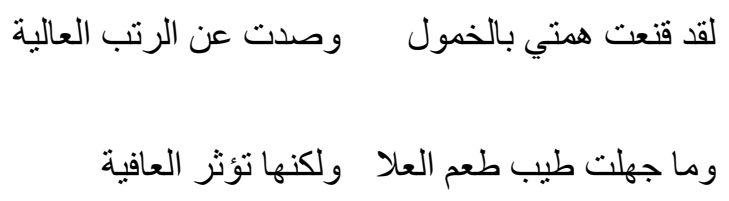

The comparison between the Judaeo-Arabic poems in this fragment to the Arabic poems reveals slight differences between the two. First, the grammatical variance between the accusative and nominative cases in rijlayka and rijlāka ("your legs") respectively. From a prescriptive grammatical point of view, the case of rijlāka is more accurate than rijlayka, since rijlayka is not in a concomitant object position in the sentence, which has to be an accusative dispensable noun that confirms its companionship, after the particle (و/wāw/) of concomitance (وفعول معد). The $w \bar{a} w$ in the sentence, however, is $w \bar{a} w$ al-hăl (the $w \bar{a} w$ of the status), after which comes a

\footnotetext{
${ }^{50}$ Ibn Khallikān, Wafayāt al-a yān, 105-106.
} 
complete sentence. The noun coming after the sentence in the poem has to be a subject (mubtada') in the nominative case. Accordingly, rijläka in the Arabic version of the poem is prescriptively more accurate than the version found in the Judaeo-Arabic fragment.

Another difference between the two versions can be found in some lexical items, like hăadat 'an (departed from) in (Ar.54.31.1v), and șaddat 'an (hold back from) in the Wafayāt al-a yān wa-

$a n b \bar{a}^{\prime} a b n \bar{a}{ }^{\prime} a l-z a m \bar{a} n .{ }^{51}$ The two verbs are used to give a similar meaning of keeping away from taking high positions.

Another piece of religious poetry reflecting Arabic invocation and prayer to God, written in the Arabic poetic metre majzü' al-ramal:

\section{T-S NS 102.108 (1r):}

יא אלאה אלעאלמין : (- n

יא ולי אלמכרמאת

אנת עפَו אלמזנבין : n

באלצחא ואדאריאת

ארחם אלכَאטי אלחזין : - n

יום ידני מן לקאך

\section{Arabic transliteration:}

\footnotetext{
${ }^{51}$ Ibn Khallikān, Wafayāt al-a yān, 105.
} 


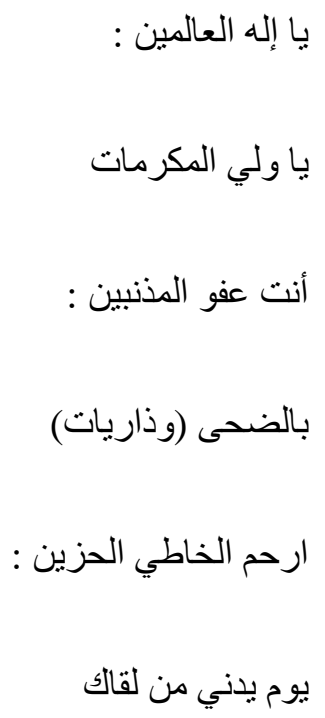

\section{Translation:}

"Lord of all creation:

The master of generosity

you are the one who forgives the guilty

in the daylight (and at night?). ${ }^{52}$

give your mercy to the mistaken and the sad

when he is about to die (literary: to meet you)."

An example of a very popular Arabic poem used widely in the Islamic world is the poem in T-S

Ar.13.4 by 'Alī ibn Abī Țālib (600-660), the cousin of the prophet Muhammad. It is interesting

52 In the Judaeo-Arabic fragment it reads ואדאריאת. The possible Arabic reading could be $w$-al- $\underline{d}$ ariāt, meaning strong winds. However, the word does not go with the meaning of the verse. 
to note that a poem by a famous Islamic figure like 'Alī ibn Abī Ṭâlib was copied into JudaeoArabic and read by Jews.

The poem version in the fragment is written in the Arabic poetic metre al-basit :

T-S Ar.13.4 (2r)

לא תטלם" אדא כנת מקתדראً פאלטלם אכרה יאתיך

באלנדמי ، תנאם עינאך ועין אלמטלום מנתבהא

ידעו עלי[ר] ועין אללה לם תנמי

\section{Arabic transliteration:}

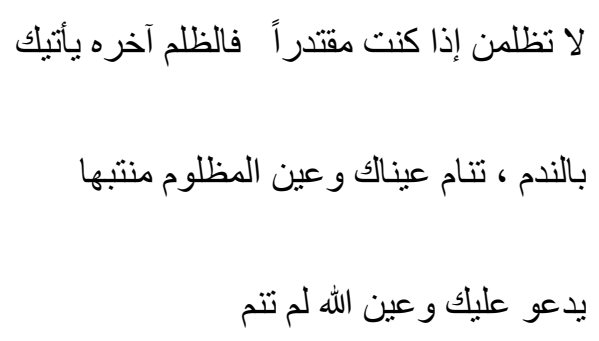

\section{Translation:}

"Do not oppress when you are able to do so. Oppression brings to you, in the end,

regret. Your eyes fall asleep and the eye of the oppressed stays awake.

He invokes (God) against you, and the Eyes of God never sleep." 
While there is an Arabic version of the poem in which the first verse is equal to the poem in the Judaeo-Arabic fragment, ${ }^{53}$ there is another Arabic version of the same poem that reads entirely

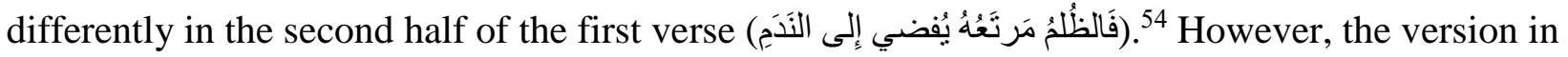
Arabic sources is slightly better than the version in the Judaeo-Arabic fragment regarding Arabic poetic metre. The poem in the fragment does not follow the proper pattern of the Arabic poetic metre al-Basit (the simple) in either the first or second verse in comparison to what appears in the Diwān of 'Alī ibn Abī Ṭālib:"55

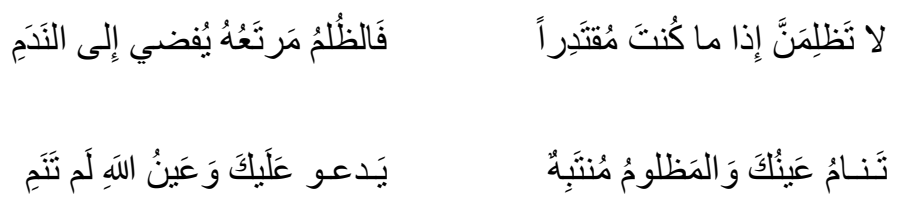

Based on the poems discussed above, one can easily say that various genres of Islamic poetry were copied into Judaeo-Arabic sources. This fact confirms that wide-ranging poetic themes were read by Jews during medieval and early modern times.

\subsection{Poetry for Grammar and eloquence}

The collection of Arabic poems preserved in the Cairo Genizah contains a fragment that might be taken from a complete handbook which discusses some Arabic linguistic and rhetorical issues using a poetic text. The poem under discussion is written in a literary style which comes in verses that have one poetic metre. However, each verse follows a different rhyme, unlike the familiar

\footnotetext{
${ }^{53}$ Ab̄̄ l-Ḥasan al-Bașrī, Minhāj al-Yaqīn, ed. Uways Wafā ibn Muḥammad Khān Zādah (Astana: Maḥmūd Bek Printing, 1910), 40.

54 'Alī ibn Abī Ṭālib, Dīwān Amīr al-Mu'minīn al-Imām 'Alì ibn Abī Ṭālib, ed. 'Abd al- 'Azīz Karam (Beirut: alMaktaba al-Thaqāfiiyya, 1988), 184.

55 'Alī ibn Ab̄̄ Ṭālib, Dīwān Amīr al-Mu’minīn, 184.
} 
Arabic poetic style, in which a single poem has one rhyme and one poetic metre for all its verses. The verses below, written in al-ragaz Arabic poetic metre, are taken from a poem which describes the proper Arabic writing style:

T-S Ar.37.144 (1v) $)^{56}$

פציל

פי מואנע פהם אלמעני מן

אללפט

ואנמא צעובה אלכלאם . יכון מן רדאה אלנטאם

או שדה אלאיגאז ואלתטויל . ולטף מענאה ען אלעקול

או יך מן גראבה אלאלפאט. . וכונהא תנבו ען אלחפ־אט.

או כאן לפט ס.י אלעבארה . או קצר אלרמוז ואלאשארה

\section{Arabic transliteration:}

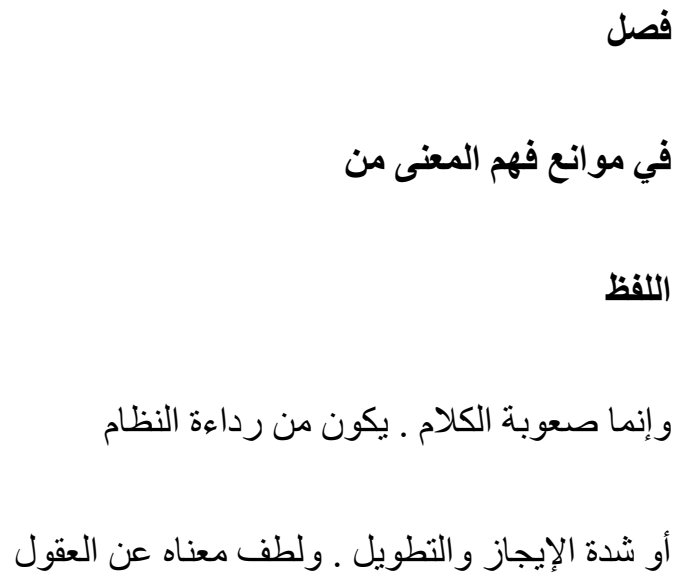

${ }^{56}$ The title of the poem in the Judaeo-Arabic fragment appears in a larger bold font, highlighted here in bold. 


$$
\text { أو يك من غر ابة الألفاظٍ ـ وكونها تتبو عن الحُفّاظٍ }
$$

\section{Translation:}

\section{"Chapter}

\section{On the stoppages of comprehending the meaning}

\section{of words}

The unclear discourse is caused by awkward use of prose

Or caused by the extreme shortage or abundance (of words), (that come) with hidden meaning,

Or contain peculiar words, which deviate from the known,

Or have weak expression, limited in notions and reference."

This poem, along with other examples from the same fragment, constitutes a proof of the unique position of reading poetry among Jews at the time. Even Arabic rhetoric, grammar and eloquence, which are described in poetic style in the fragment, were among the materials that were copied into Judaeo-Arabic.

\section{Poetry written in Arabic script in the Cairo Genizah}

Not all Arabic language poetry found in the Genizah is written in Hebrew script (Judaeo-Arabic), the Collections hold some fragments in Arabic script as well, which may indicate that poetry also circulated in Arabic script in Jewish households. 
Among the most important fragments is a small piece of an Arabic fragment written in a beautiful early handwriting. This piece is written on parchment (hence potentially predating the introduction of paper into Egypt) and is part of a very well-known book of Arabic literature, al'Iqd al-Farīd (The Unique Necklace), written by the poet and writer Ibn 'Abd Rabbih (860-940). The fragment T-S Ar.38.3 is a small part left from a severely damaged page. Using Arabic poetry databases, a poem of two verses was first identified. Comparison with the databases showed that the whole piece was taken from the book al- Iqd al-Farìd. ${ }^{57}$ The short poem found in the fragment reads:

T-S Ar.38.3 (1r)

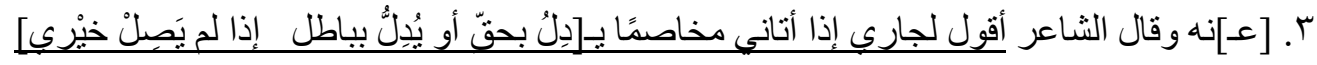

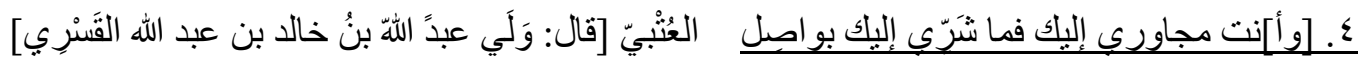

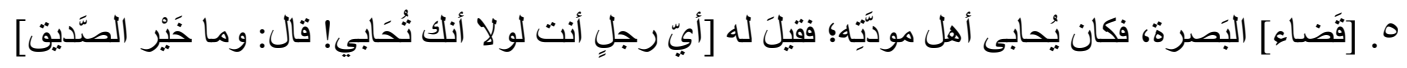

$$
\begin{aligned}
& \text { T. إذا لم يَقْطع لصديقه قِطْعة من دينها... }
\end{aligned}
$$

\section{Translation of the poem (underlined):}

"I shall tell my neighbour, if he comes to blame me, whether he is right or wrong: 'If my welfare did not reach you, though you are my neighbour, then my harm will not reach you either'."

\footnotetext{
${ }^{57}$ Ibn 'Abd Rabbih, Kitāb al- 'Iqd al-farīd, ed. Mufīd Muhammad Qumīḥa (Beirut: Dār al-kitāb al- 'arabī, 1984), II: 207.
} 
The fragment T-S Ar.30.6 holds another poem preserved in Arabic script. The love poem is written in cursive handwriting and comes in three verses. On the same page of the fragment, there are two lines, apparently from another Arabic poem, written in Hebrew script. The poem belongs to the Abbasid poet al-Wazīr al-Muhallabī (903-963), who composed it in Arabic poetic metre al-kāmil.

T-S Ar.30.6 (1v):

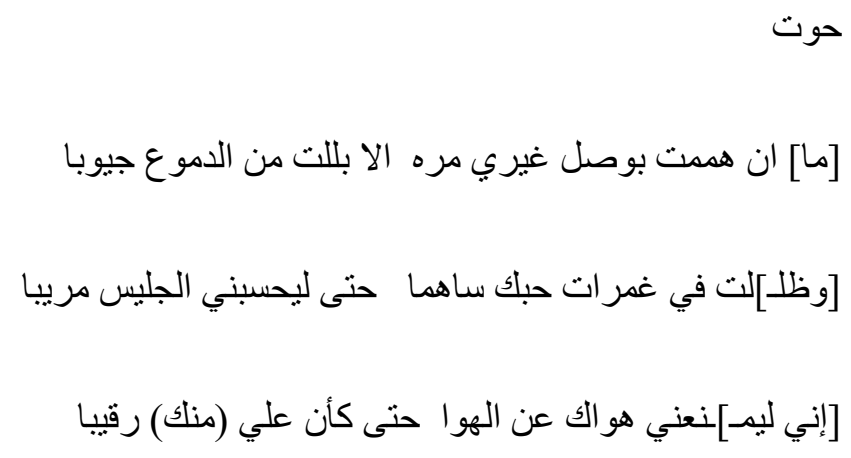

\section{Translation:}

"It contains

Once you turned to someone else, I made my collar wet with tears.

I remained unconscious in the deluge of your love, so that people sitting nearby thought that I was suspicious.

Your passion prevents me from (finding another) love, as if there is an observer (hired by you) who watches me." 
This poem is found in the Arabic poetry databases. However, it reads differently from the version in the fragment: ${ }^{58}$

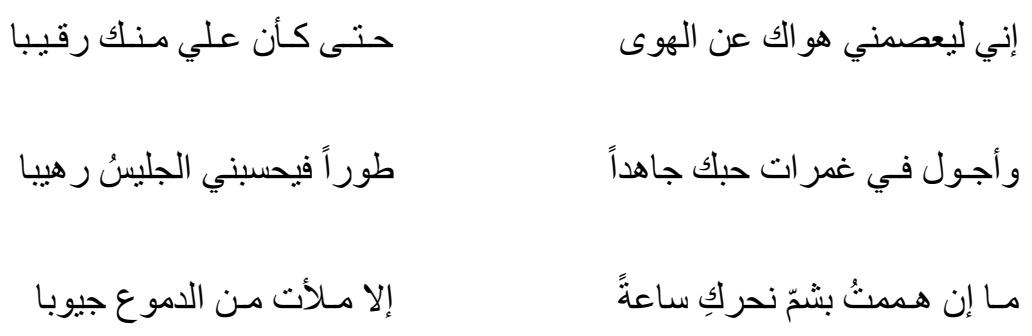

\section{Translation:}

"Your passion prevents me from finding another love, as if there is an observer (hired by you) watching me.

I wander through the deluge of your love fervently, in a way that people sitting nearby think that I am terrifying.

Once I start smelling your neck, I make my collar wet with tears.”

The comparison between the two versions, although both are written in Arabic script, reveals some differences. The first point is related to verse order; the first verse in the Cairo Genizah fragment comes as the last verse in the Arabic version in the book Mu 'jam al- 'Udaba ' (the writers' lexicon), ${ }^{59}$ and vice versa. The second variation is located in the first half of the first verse in the fragment (مال ان هممت بوصل غيري مره]), which is written as (مـا إن همدتُ بشمّ نحركِ ساعةً) in $M u$ ' jam al- 'Udaba' '. There are also some other differences between the two versions in terms

58 Yāqūt ibn 'Abd Allāh al-Hamawī, Mu 'jam al-'Udabā': Irshād al-arīb ilā ma 'rifat al-ad̄̄b, ed. Iḥsān 'Abbās (Beirut: Dār al-Gharb al-Islāmī, 1993), III: 992.

59 Al-Hamawī, Mu 'jam al- 'Udabā', III: 992. 
of words. For instance, the words رهيباً، طوراً، ليعصمني) in the fragment, which appear as ( ريبياً in the book Mu 'jam al- 'Udabä' respectively.

The recto of the fragment T-S Ar.30.6 contains an Arabic poem written in Hebrew script.

The poem in the fragment belongs to a well-known Abbasid poet called Abū Firās al-Hamadān̄̄ (932-967). The theme of the poem is love, and it is written in Arabic poetic metre al-bāsitt:

T-S Ar.30.6 (1r)

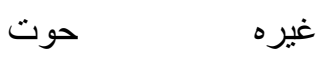

[ס]כרת מן לחצה לא מן מדאמתה ומאל באלנום ען עי[ני]

תמאילה

ומא אלסל[אף] [..] בל סואלפּה ולא אלשמול בלאני ב[ל]

שמאילה

אלוא בעזמי אצדאג לויי לה וגזאל צברי מא תחוי

גלאילה

\section{Transliteration:}

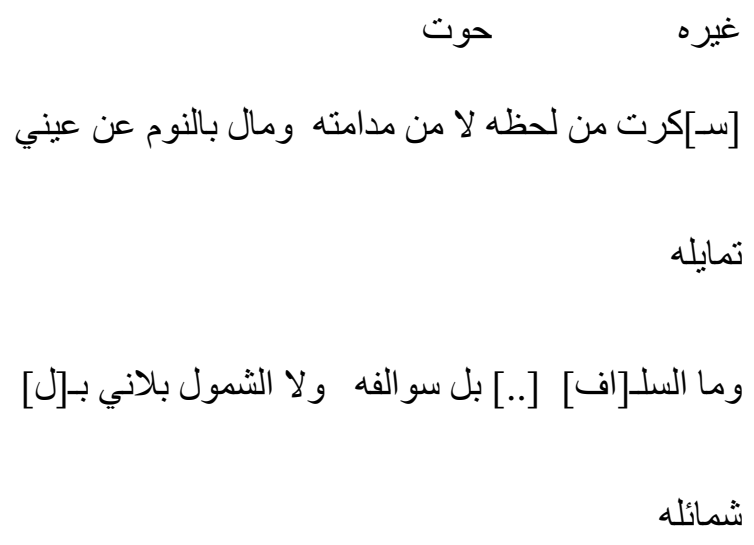




$$
\text { ألوا بعزمي أصداغ لويي لله وغال صبري ما تحوي }
$$

غلائلَه

\section{Translation:}

“another poem, contains:

I was made drunk by seeing her, not by (drinking) her wine. Her dance took the sleep away from

my eyes

It was she, not the wine, that made me crazy. It was her charisma, not the cold wine, that

afflicted me.

My power was ruined by my cheeks, which are submitted to her. She stole my heart, so it (my heart) is free from

betrayal."

The version of the Arabic poem in Arabic books is quite the same as in the JA version, there is only one difference between the two versions, which is the verb (إزدَدَتنتي-belittled me) and the verb (بلاني - afflicted me): ${ }^{60}$

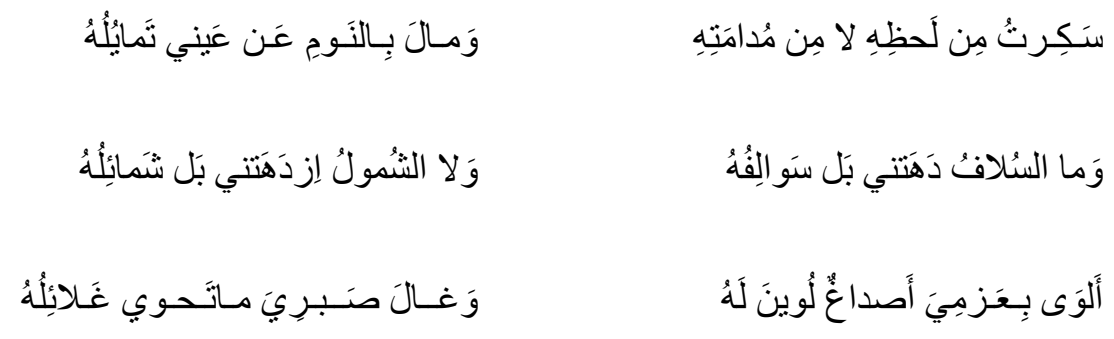

${ }^{60}$ Abū Firās al-Ḥamadānī, Sharh Dīwān Abū Firās al-Hamdānī, ed. Khalīl Al-Diwīhī (Beirut: Dār al-fikr al- 'arabī, 1994), 260. 
The poem in Hebrew script is headed by Arabic script words (غيره حوت), meaning “another poem contains". It is interesting to note that the Arabic handwriting of this word is very similar to the poem written in Arabic script in the verso of the same fragment. Apparently, the same scribe wrote both the Judaeo-Arabic and Arabic poems in this fragment, which raises some questions concerning the context: Why would a Jewish scribe write Arabic poetry in both Arabic and Hebrew script in a single document? Has this anything to do with the audience? And for what purpose would the lines have both Arabic and Hebrew script interchangeably? More research is required to reveal the reasons behind this phenomenon.

\section{The Cairo Genizah and the study of Arabic literature.}

The Cairo Genizah has preserved thousands of fragments that have completely changed scholarly understanding of Jewish culture and history in the Middle East from the medieval period until modern times. The importance of Genizah sources for Arabic Studies is now increasingly appreciated by scholars, and the poems discussed in this paper reveal illuminating examples of Abbasid, Fatimid and Ottoman Arabic poetry preserved in the Collections.

The comparison between Arabic poems in the Judaeo-Arabic fragments and the poems found in Arabic poetry databases shows, many times, differences between the two. These variations occur mostly at the lexical level, mainly of synonyms of Arabic terms. Another notable variation can be found in the way that verse order was different in a single poem between the two sources.

The most significant feature of the Cairo Genizah fragments in this paper, however, is that some fragments have extra verses, or sometimes parts in the case of muwashshah, that are missing from Arabic poetry databases. 
To give an example, the fragment T-S Ar.37.127 holds a poem that might belong to an Abbasidperiod poet called Khālid al-Kātib (d.876), who was famous for his romantic Arabic poetry. The poem starts with two verses, which are almost the same as Khālid al-Kātib's poem available in his Dīwān. ${ }^{61}$ However, the rest of the poem in the fragment is different from the Arabic version available to us. The Judaeo-Arabic poem is four verses long, which makes it two verses longer than the currently existing Arabic version. There are also some different words used in the first two verses of the poem in the two versions. The poem's metre and rhythm, though, are the same in the two versions, which are written in the Arabic poetic metre majzu' al-ramal:

\section{T-S Ar.37.127}

כלמא אשתד כצועי אלדי בין צלועי

פי דמנת אל כד כיול מן דמועי לא תלומנא

אד בכינא והממנא באל רגועי כל מא א

אבצרת רבעא דארס פאצוֹ דמועי

\section{Arabic transliteration}

${ }^{61}$ Khālid al-Kātib, Dīwān Khālid al-Kātib, ed. Karin Sadir (Aleppo: Publications of Syrian Ministry of Culture, 2006), 399. 


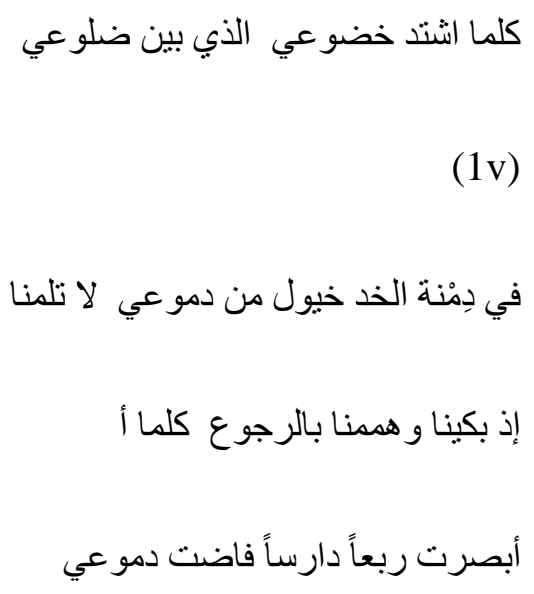

\section{Translation:}

"Every time my submission increases, the submission which is between my ribs,

horses of my tears ${ }^{62}$ are in the ground of my cheek. Do not blame us

if we cry and intend to return. Every time

I see an effaced house my tears flow".

Whereas the version found in the Diwān by Kạlid al-Kātib reads: ${ }^{63}$

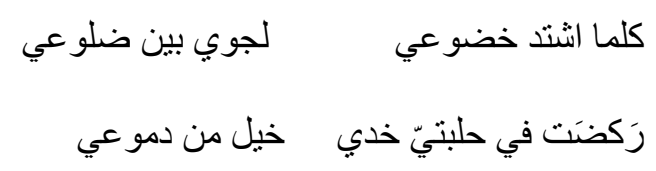

"Every time my submission increases, because of the love between my ribs, horses of my tears run in the racecourse of my cheek".

${ }^{62}$ The poet compares between the tears and the horses. Like horses, tears run in the ground of his cheek.

${ }^{63}$ Al-Kātib, Dīwān Khālid al-Kātib, 399. 
The oldest Arabic manuscript we have of the Diwān by Khālid al-Kātib is a copy dated to the year $1698 .{ }^{64}$ From the style of the Genizah fragment in terms of its Arabic vocalisation and the Hebrew script used, one can estimate that the fragment is roughly dated to the thirteenth to fourteenth centuries. This suggests that the poem found in the fragment could be the oldest extant version of the Arabic poem written by the Abbasid-poet Khālid al-Kātib. This is not the only case in which Judaeo-Arabic poems found in the Genizah fragments differ from the Arabic poems available in Arabic poetry databases. The poems discussed above in this paper show that other fragments in the Cairo Genizah Collections reveal the same phenomena. ${ }^{65}$

This article highlights, albeit briefly, the diversity of themes and genres of Arabic poetry read by Jews in medieval and early modern Egypt. A random survey of Genizah fragments showed poems mainly written in Hebrew script (that is, in Judaeo-Arabic) and fewer written in Arabic script. The topics are varied, including secular and religious poetry, although love poetry is the dominant theme. The most important feature of the Cairo Genizah poetry presented here is verses, even complete parts, of famous poems which have only been preserved in Judaeo-Arabic fragments. The findings also suggest that the Genizah has preserved some Arabic poems in versions that are several hundred years older than the extant manuscripts from other collections and, therefore, demonstrates how useful and vital the Cairo Genizah could be for the recovery of lost works, or of more original versions.

This paper, however, does not claim that the Judaeo-Arabic fragments provide the more correct versions of the Arabic poems in comparison to existing Arabic poetry sources. Nor does it

\footnotetext{
${ }^{64}$ Al-Kātib, Dīwān Khālid al-Kātib, 40-41.

${ }^{65}$ See for instance the muwashshah section in this paper.
} 
underestimate the quality of the Arabic poetry in the Cairo Genizah because of the minor "mistakes" (according to prescriptive grammar) in terms of grammar and Arabic poetic metres in some of the poems discussed above. It does, however, emphasise the importance of the Cairo Genizah as a prospective contributor to and an abundant source for the diachronic and historical study of Arabic literature and Arabic poetry, and stresses the need for further studies of Arabic poetry in the Cairo Genizah.

Having often been written in Hebrew script and having been kept in the Genizah, the Arabic poetry in the Cairo Genizah also evokes some broader questions: for what purposes were these Judaeo-Arabic copies produced? The fact they were written in Judaeo-Arabic means that Arabic poetry in Hebrew script was being circulated among Jews. The question is for what kind of readership? Were the readers the educated Jewish elite, themselves poets, who were reading them in order to acquire knowledge for their poetic works? If so, why did this elite not read them in Arabic script, or why did they prefer to read them in Hebrew script? If the use of script had to do with education, was it actually the educated middle classes, like merchants, for whose pleasure these manuscripts were produced? Were the fragments part of a project to copy popular Arabic books about literature and poetry into Judaeo-Arabic, like the Karaite scribes who copied a number of Arabic Sufi books into Judaeo-Arabic? The study of Arabic poetry in the Cairo Genizah arouses thought-provoking questions, and therefore, suggests possible new and illuminating avenues of inquiry. 